\title{
Improving legal knowledge about marriage and limitation of marriage in Integrated Islamic High Schools Al Fityan Medan
}

\author{
Dedi Harianto $^{1 *}$, Utary Maharany ${ }^{1}$, Mulhadi $^{2}$, Rafiqoh Lubis $^{3}$, Yusrin $^{4}$ \\ ${ }^{1}$ Faculty of Law, Universitas Sumatera Utara \\ *Email: dedifhusu@yahoo.co.id
}

\begin{abstract}
According to the central Bureau of statistical report, early marriage among the younger generation in Indonesia shows symptoms of improvement. This is a violation of marital law provisions and the potential to cause negative impacts in form of divorce and an increase in marital mortality during childbirth. To overcome these problems, it is necessary to provide additional legal knowledge to students in the form of legal counseling, question and answer, and discussion of marital law and marital age limits, as well as the donation of marriage law books. Based on the results of the evaluation, it was concluded that there was an increase in student knowledge about marital law and marital age limits, refers to the analysis of the questions asked by students in the question and answer session, as well as a summary of the results of group discussion submitted by representative of each group.
\end{abstract}

Keywords : Early marriage, young generation

\begin{abstract}
Abstrak
Menurut Laporan Biro Pusat Statistik, pernikahan dini di antara generasi muda di Indonesia menunjukkan gejala perbaikan. Ini merupakan pelanggaran ketentuan hukum perkawinan dan berpotensi menyebabkan dampak negatif dalam bentuk perceraian dan peningkatan kematian perkawinan saat melahirkan. Untuk mengatasi masalah ini, perlu untuk memberikan pengetahuan hukum tambahan kepada siswa dalam bentuk konseling hukum, pertanyaan dan jawaban, dan diskusi tentang hukum perkawinan dan batas usia perkawinan, serta sumbangan buku-buku hukum pernikahan. Berdasarkan hasil evaluasi, disimpulkan bahwa ada peningkatan pengetahuan siswa tentang hukum perkawinan dan batas usia perkawinan, mengacu pada analisis pertanyaan yang diajukan oleh siswa dalam sesi tanya jawab, serta ringkasan dari hasil diskusi kelompok yang disampaikan oleh perwakilan masing-masing kelompok.
\end{abstract}

Kata kunci: Pernikahan dini, generasi muda

\section{PENDAHULUAN}

Di antara permasalahan hukum yang dapat ditemukan di masyarakat sebagaimana diatur dalam lapangan hukum keperdataan khususnya hukum perkawinan adalah permasalahan perkawinan di bawah umur yang kerap kali terjadi di masyarakat.

Hal ini merupakan salah satu bentuk penyimpangan terhadap ketentuan Undang-undang No. 1 Tahun 1974 Tentang Perkawinan yang telah menetapkan batas usia tertentu bagi pasangan calon mempelai yang akan melaksanakan perkawinan. Bagi calon mempelai pria harus berumur minimal 19 (Sembilan belas) tahun, sedangkan calon mempelai wanita berumur minimal 16 (enam belas) tahun. Penetapan batas umur pasangan yang akan melaksanakan perkawinan tersebut didasarkan kepada pertimbangan agar kedua belah pihak benar-benar siap dan matang dari sisi fisik, psikis dan mental dalam berumah tangga.

Fenomena perkawinan di bawah umur banyak ditemukan di berbagai pelosok daerah di Indonesia, tidak hanya di pedesaan tetapi dapat pula ditemukan hal yang serupa di Kota-kota besar. Penyebabnya juga sangat berfariasi, diantaranya berkaitan dengan masalah ekonomi, rendahnya tingkat pendidikan masyarakat, pemahaman budaya dan nilai-nilai agama tertentu, maupun karena hamil terlebih dahulu atau lebih popular disebut sebagai married by accident (Heru Susetyo, 2008 : 12). 
Berdasarkan Data Badan Pusat Statistik Tahun 2018, angka prevalensi perkawinan anak di Indonesia mengalami peningkatan menjadi $15,66 \%$ (lima belas koma enam puluh enam persen) dibandingkan tahun 2017 yaitu 14,18 \% (empat belas koma delapan belas persen). Mereka yang digolongkan melakukan perkawinan anak menurut data BPS adalah perempuan yang menikah pertama di usia 16 tahun atau kurang. Dari catatan BPS tersebut, provinsi dengan jumlah persentase pernikahan muda tertinggi adalah Kalimantan Selatan sebanyak 22,77\%, Jawa Barat (20,93\%), dan Jawa Timur $(20,73 \%)$.

Memperhatikan kondisi yang cukup memprihatinkan tersebut, telah mendorong Tim Pengabdian Masyarakat Fakultas Hukum USU untuk bepartisipasi meningkatkan pengetahuan dan kesadaran hukum kalangan generasi muda, khususnya para pelajar Sekolah Menangah Atas (SMA) akan pentingnya memperhatikan ketentuan hukum perkawinan termasuk mengenai batas usia perkawinan yang diatur dalam UU No. 1 Tahun 1974 Tentang Perkawinan.

Guna mewujudkan hal tersebut ditetapkanlah SMA Islam Terpadu Al Fityan Medan, beralamat Jalan Keluarga Lingkungan IX Asam Kumbang Kecamatan Medan Selayang, Kota Medan. Memiliki jumlah Siswa sebanyak 1075 (seribu tujuh puluh lima) siswa, terdiri dari tingkat RA, SD, SMP, SMA, Mahad Tahfiz, dengan jumlah pegawai sebanyak 201 (dua ratus satu) Orang.

\section{METODE PELAKSANAAN}

Berdasarkan identifikasi masalah yang telah dilakukan di lokasi pengabdian masyarakat yaitu SMA Islam Terpadu Al Fityan Kota Medan, maka ditetapkan metode yang digunakan dalam kegiatan pengabdian masyarakat ini berupa penyampaian materi dalam bentuk ceramah, kemudian dilanjutkan dengan sesi tanya jawab secara langsung dengan dipandu moderator. Melalui ceramah penyuluh dapat menyampaikan materi-materi yang penting untuk diketahui dan dipahami perserta penyuluhan sedangkan melalui Tanya jawab dapat melengkapi materi yag belum jelas serta untuk membantu memberi masukan atas permasalahan yang dihadapi para siswa SMA Islam Terpadu Al Fityan Kota Medan dalam memuaskan keingintahuan peserta mengenai segi segi hukum perkawinan dan batas usia perkawinan. Kemudian kegiatan dilanjutkan dengan penyerahan buku-buku hukum perkawinan untuk melengkapi koleksi perpustakaam sekolah.

Selain keaktifan dari tim pengabdian masyarakat Fakultas Hukum USU dalam merencanakan teknis kegiatan penyuluhan dan materi penyuluhan serta personel yang akan menyampaikan materi penyuluhan. Pihak Yayasan Al Fityan yang diwakili oleh Pimpinan SMA Islam Terpadu Al Fityan mengarahkan sekitar 60 (enam puluh) siswa SMA kelas 12 beserta beberapa orang guru pendamping untuk menjadi peserta aktif dalam kegiatan pengabdian masyarakat ini, dengan pertimbangan bahwa siswa kelas 12 sudah mendapatkan materi pelajaran mengenai Hukum Perkawinan Islam dari para guru di kelas masing-masing, serta akan bertambah lengkap dengan mendengarkan dan berdiskusi dengan tim pengabdian masyarakat mengenai hukum perkawinan berdasarkan hukum nasional yaitu UU No 1 Tahun 1974 Tentang Perkawinan dan beberapa putusan pengadilan.

\section{HASIL DAN PEMBAHASAN}

Rangkaian pelaksanaan kegiatan pengabdian masyarakat yang digagas oleh Tim Pengabdian Masyarakat (Abdimas) Fakultas Hukum USU di mulai dengan mengadakan pertemuan pada tanggal 21 Agustus 2019 dengan Mitra Abdimas, yaitu Ketua Yayasan Al Fityan Medan dihadiri unsur Pimpinan SMA Islam Terpadu guna menentukan tanggal pelaksanaan abdimas, siswa peserta abdimas, tempat pelaksanaan abdimas serta ketersediaan fasilitas penunjang kegiatan abdimas.

Pada pertemuan tersebut tim abdimas Fakultas Hukum USU menyampaikan maksud kunjungan ke Yayasan Al Fityan Medan untuk mengadakan kerjasama pelaksanaan kegiatan abdimas dalam bentuk penyuluhan hukum dengan tema berkaitan "Hukum Perkawinan dan Batas Usia Perkawinan." Ketua Yayasan Al Fityan beserta jajarannya menyambut baik kerjasama tersebut dan memandang penting adanya penyuluhan mengenai Hukum Perkawinan dan Batas Usia Perkawinan guna 
menambah pengetahuan dan pemahaman siswa Yayasan Al Fityan Medan, apalagi terdapat mata pelajaran "Hukum Perkawinan Islam" yang diberikan kepada siswa kelas 12 SMA Al Fityan.

Dari hasil pertemuan tim abdimas Fakultas Hukum USU dengan Ketua Yayasan Al Fityan dan Pimpinan SMA Al Fityan disepakati bahwa pelaksanaan abdimas akan diselenggarakan pada hari kamis tanggal 5 September 2019 bertempat di aula siswa Yayasan Al Fityan, dengan melibatkan sekitar 65 (enam puluh lima) siswa kelas 12 beserta beberapa orang guru pendamping.

Sesuai dengan tanggal pelaksanaan abdimas yang telah disepakati, tim abdimas Fakultas Hukum USU kembali mendatangi lokasi Yayasan Al Fityan, beralamat di Jalan Keluarga Lingkungan IX Asam Kumbang Kecamatan Medan Selayang Medan. Sebagai tambahan informasi, saat ini Yayasan Al Fityan Medan memiliki jumlah siswa sebanyak 1075 (seribu tujuh puluh lima) siswa, terdiri dari Raudhatul Athfal (RA), Sekolah Dasar (SD), Sekolah Menengah Pertama (SMP), Sekolah Menengah Atas (SMA), Mahad Tahfiz, dengan jumlah pegawai sebanyak 201 (dua ratus satu) orang.

Kegiatan abdimas dilaksanakan pada hari kamis, tanggal 5 September 2019 bertempat di Aula Siswa Al Fityan. Tim abdimas terdiri dari 5 (lima) orang dosen dibantu oleh 5 (lima) orang mahasiswa Fakultas Hukum USU, sedangkan jumlah siswa peserta abdimas terdiri dari 65 (enam puluh lima) siswa kelas 12 dengan beberapa orang guru pendamping.

Acara abdimas dimulai pada pukul 9.00 WIB dengan kata pembuka dari 2 (dua) orang mahasiswa sebagai pemandu acara abdimas yang menyampaikan susunan acara pengabdian masyarakat. Dilanjutkan dengan kata sambutan dari Ketua Tim Abdimas Fakultas Hukum USU, sekaligus memperkenalkan satu persatu personil tim abdimas serta personil pendukung yang terdiri dari beberapa orang mahasiswa. Dari pihak Yayasan Al Fityan Medan turut memberikan kata sambutan Ketua SMA Alfityan Medan yang pada pokoknya sangat mendukung terselenggaranya kegiatan abdimas bagi menambah pengetahuan siswa mengenai hukum perkawinan nasional dan ketentuan mengenai batas usia perkawinan. Selama ini materi hukum perkawinan yang dipelajari siswa Yayasan Al Fityan lebih kepada kajian berdasarkan ketentuan Hukum Islam, mengacu kepada Al Quran dan hadist.

Pada sesi acara utama, dihadirkan 2 (dua) orang narasumber dari tim abdimas Fakultas Hukum USU yang menyampaikan materi penyuluhan hukum yang berjudul "Aspek Hukum Perkawinan di Indonesia" dan "Batas Usia Perkawinan dalam Hukum Perkawinan Indonesia". Narasumber pertama pada pokoknya menjelaskan kepada peserta abdimas mengenai hakekat dari lembaga perkawinan bagi pasangan suami istri, sebagai "penyatuan ikatan lahir batin antara seorang pria dengan seorang wanita sebagai suami istri dgn tujuan membentuk keluarga (rumah tangga) yang bahagia dan kekal berdasarkan Ketuhanan yang Maha Esa", dasar hukum pengaturan perkawinan di Indonesia sebagaimana di muat dalam UU No. 1 Tahun 1974 Tentang Perkawinan serta berbagai peraturan pelaksana lainnya, keberadaan buku nikah, syarat formil dan materil perkawinan, serta kewajiban administrasi pencatatan perkawinan.

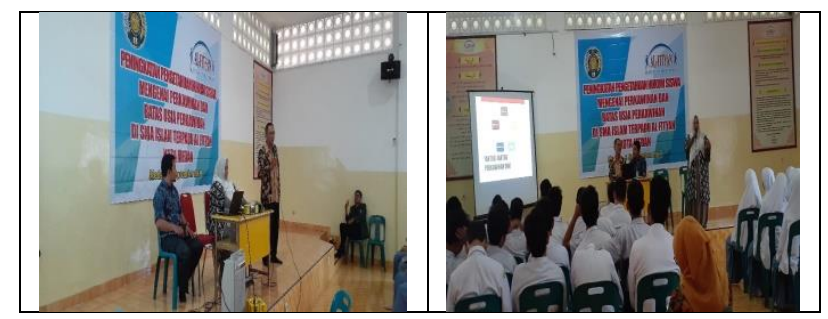

Gambar 1 : Sesi penyampaian materi oleh narasumber

Narasumber kedua pada pokoknya menyampaikan secara khusus materi berkenaan dengan batas usia perkawinan, didahului dengan pemutaran video singkat mengenai realita terjadinya perkawinan usia dini di Indonesia, dan dilanjutkan pemaparan materi dengan mangulas data statistik perkawinan anak dari Badan Pusat Statistik yang menunjukkan masih tingginya penyebaran perkawinan anak di seluruh provinsi di Indonesia, dan menunjukkan gejala peningkatan pada tahun 2018 dibandingkan dengan tahun 2017, sehingga menempatkan Indonesia berada dalam kondisi 
"darurat perkawinan anak". Latar belakang terjadi perkawinan anak serta dampak negatif pernikahan anak bagi pasangan suami istri.

Setelah sesi penyampaian materi dari narasumber, kegiatan abdimas dalam bentuk penyuluhan hukum dilanjutkan dengan sesi diskusi dan tanya jawab. Pada kesempatan tersebut cukup banyak pertanyaan-pertanyaan diajukan oleh siswa peserta penyuluhan untuk memuaskan rasa keingintahuan mereka. Di antara pertanyaan-pertanyaan tersebut berhubungan dengan fenomena perkawinan campuran, perkawinan beda agama, pencatatan perkawinan, serta izin menikah bagi pasangan yang akan melaksakan perkawinan anak.

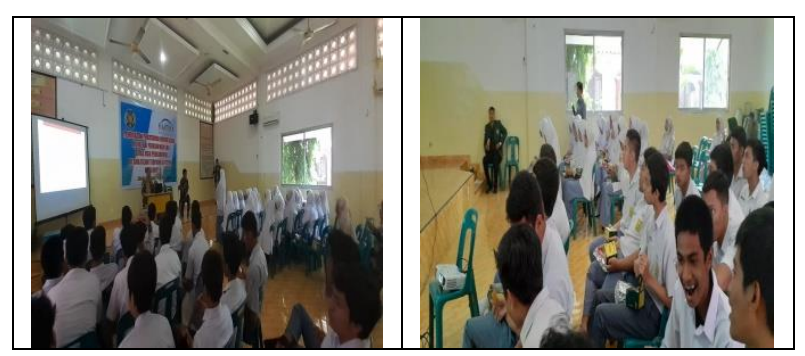

Gambar 2. Sesi diskusi dan tanya jawab

Dari rangkaian pertanyaan yang diajukan terlihat kesungguhan dan rasa inggin tahu yang cukup tinggi di kalangan siswa SMA Al Fityan mengenai berbagai segi hukum perkawinan di Indonesia, serta ungkapan rasa keprihatinan mengenai fenomena peningkatan perkawinan anak di Indonesia, serta harapan agar di masa depan pemerintah melalui lembaga instansi terkait bekerjasama dengan masyarakat, termasuk kalangan perguruan tinggi guna menekan terjadinya perkawinan anak di Indonesia. Dari diskusi dengan narasumber, umumnya siswa peserta penyuluhan memiliki keingginan besar untuk melanjutkan pendidikan ke jenjang lebih tinggi pada berbagai perguruan tinggi di seluruh Indonesia, sehingga implikasinya secara langsung akan menghindari partisipasi siswa Al Fityan Medan pada terjadinya fenomena perkawinan anak.

Untuk menjalin kesinambungan pengetahuan siswa tentang hukum perkawinan agar tidak sebatas hanya sampai pada saat pelaksanaan abdimas keinggintahuan mereka dapat dipenuhi, tim abdimas berinisitif untuk menyumbang beberapa judul buku mengenai hukum perkawinan sebagai tambahan koleksi perpustakaan Yayasan Al Fityan Medan, serta menyerahkan foto copy materi penyuluhan hukum kepada beberapa guru pendamping, guna memperkaya bahan materi pembelajaran mengenai hukum perkawinan di kelas.

Pada sesi ini juga turut diserahkan oleh Tim Abdimas Fakultas Hukum USU Plakat ucapan terima kasih dari Tim Abdimas atas bantuan dan kerjasama Yayasan Al Fityan Medan sehingga rangkaian persiapan dan pelaksanaan abdimas dapat terselenggara dengan baik.

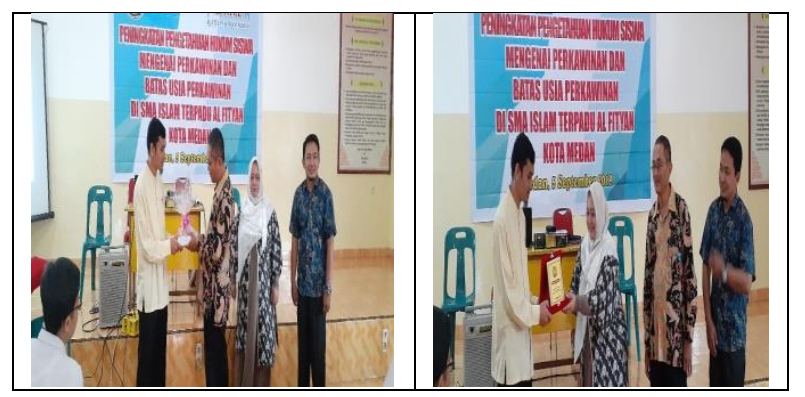

Gambar 3 : Penyerahan buku dan plakat abdimas 
Penutup dari rangkaian kegiatan abdimas disemarakkan dengan sesi acara berfoto bersama tim abdimas Fakultas Hukum USU dengan siswa peserta penyuluhan hukum dan beberapa guru pendamping serta pimpinan Yayasan Al Fityan Medan.

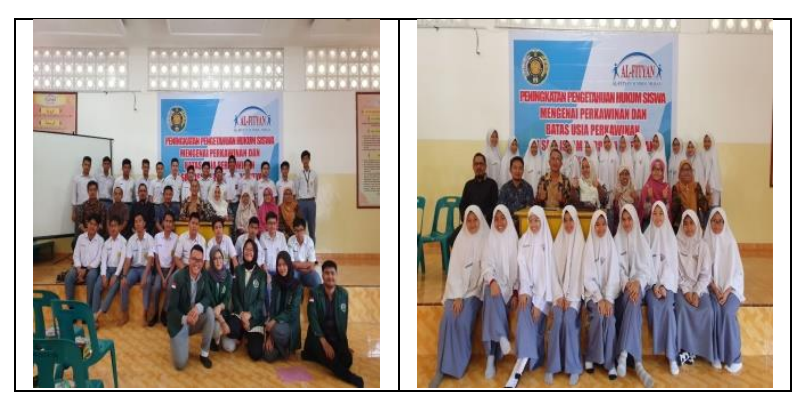

Gambar 4 : Sesi Foto bersama

\section{KESIMPULAN}

Pemerintah telah berupaya untuk mengurangi terjadinya perkawinan dini dengan telah menetapkan batas usia perkawinan dalam UU No 1 Tahun 1974 Tentang Perkawinan, di mana telah ditentukan batas usia yang diperbolehkan untuk melaksanakan perkawinan bagi calon mempelai lakilaki yaitu 19 tahun sedangkan bagi calon mempelai wanita yaitu 16 tahun, bagi pasangan yang akan melangsungkan perkawinan tetapi belum berusia 21 tahun diharuskan lagi untuk mendapatkan izin dari orang tua.

Peningkatan perkawinan dini di Indonesia pada kurun waktu 2017 dan 2018 menimbulkan kekhawatiran tidak tercapainya peningkatan kualitas sumber daya manusia (SDM) di Indonesia disebabkan perkawinan usia dini, sehingga kalangan generasi muda yang tidak menyelesaikan jenjang pendidikannya sampai ke perguruan tinggi, serta merintis karir/pekerjaan yang baik karena terbebani dengan masalah rumah tangga.

Upaya melakukan sosialisasi mengenai hukum perkawinan dan batas usia perkawinan dalam bentuk penyuluhan hukum kepada generasi muda sangat efektif untuk mencegah perkawinan dini. Penambahan wawasan pengetahuan mengenai hukum perkawinan dan batas usia perkawinan mampu membuka cakrawala berpikir generasi muda mengenai usia yang ideal untuk melangsungkan perkawinan dengan mempertimbangkan kematangan berfikir, kemampuan ekonomi dan kesiapan fisik pasangan yang akan melangsungkan perkawinan. Sehingga problematika yang kerap mengiringi perkawinan dini dapat dicegah, misalnya percekcokan dalam rumah tangga yang berakibat perceraian, kematian ibu hamil, penelantaran keluarga, dan sebagainya.

Hasil evaluasi pelaksanaan pengabdian masyarakat dalam bentuk kegiatan penyuluhan hukum, dibarengi diskusi dan tanya jawab, dinilai berhasil mencapai tujuan yang telah ditetapkan, ditinjau dari penyampaian rangkuman materi penyuluhan hukum oleh beberapa siswa, serta pertanyaanpertanyaan yang diajukan siswa peserta penyuluhan hukum dinilai sangat berbobot, dengan cakupan pertanyaan yang sangat beragam, mulai dari dampak negatif perkawinan dini, syarat- syarat perkawinan, perkawinan campuran, serta hal yang berkaitan dengan keabsahan perkawinan beda agama, pencatatan perkawinan dan sebagainya. Sehingga ke depan dengan bertambahnya pengetahuan siswa mengenai perkawinan dini, kasus-kasus yang melibatkan siswa yang melakukan perkawinan dini dapat berkurang.

\section{UCAPAN TERIMAKASIH}

Terselenggaranya kegiatan pengabdian masyarakat ini serta penulisan jurnal pengabdian masyarakat ini tidak dapat dipisahkan dari dukungan pendanaan Non PNBP Universitas Sumatera Utara dalam Skema Dosen Wajib Mengabdi dengan Surat Perjanjian Penugasan Pengabdian 
Masyarakat Program Mono Tahun Tahun Anggaran 2019 Nomor :836/UN5.2.3.2.1/PPM/2019 Tanggal 23 Juli 2019. Untuk itu Tim Abdimas Fakultas Hukum USU mengucapkan terima kasih kepada Rektor Universitas Sumatera Utara serta Ketua dan Sekretaris serta staf Lembaga Pengabdian Kepada Masyarakat Universitas Sumatera Utara. Ucapan terima kasih juga ditujukan kepada Pimpinan Yayasan Al Fityan Medan khususnya Ketua SMA Islam Terpadu Al Fityan Medan beserta guru-guru pendamping. Demikian pula ucapan terima kasih ditujukan kepada Tim Abdimas FH USU Medan serta beberapa mahasiswa yang telah mendukung kesuksesan kegiatan abdimas.

\section{DAFTAR PUSTAKA}

Usman, R. (2003). Pilihan Penyelesaian Sengketa di Luar Pengadilan. Bandung: Citra Aditya Bakti

Utsman, S. (2013). Dasar-dasar Sosiologi Hukum, Makna Dialog antara Hukum dengan Masyarakat, Yogyakarta: Pustaka Pelajar

Sikumbang, J. (2010). Mengenal Sosiologi dan Sosiologi Hukum. Medan: Pustaka Bangsa Press

Soekanto, S. (2000). Sosiologi Suatu Pengantar. Jakarta: Rajawali Press

Susetyo, H. "Pernikahan Di Bawah Umur : Tantangan Legislasi dan Harmonisasi Hukum". Jurnal Hukum dan Masyarakat, Vol. III No. 12 Tahun 2008.

Sofyan, A, \& M, L. Tulisan dalam Diskursus dan Penelitian Tim Pusat Kajian dan Perlindungan Anak (PKPA), http://www.m.kompas.com.magelang. Diakses tanggal 2 Mei 2019.

Koran Sindo, “Angka Pernikahan Dini Jumlahnya Meningkat", https://nasional.sindonews.com/read/1396184/15/angka-pernikahan-dini-jumlahnya-meningkat1555377616, di akses tanggal 1 September 2019.

Profil Yayasan Al Fityan Medan, https://alfityanmedan.sch.id/sd/about-us/, di akses tanggal 1 September 2019. 